4 Nissinen A, Tuomilehto J, Salonen JT, Kottke TE, Piha T. The influence of socioeconomic factors on blood pressure control during a community-based hypertension control programme. Acta Cardiol 1986;41:99-109.

5 Mann $\mathrm{AH}$. The psychological effect of a screening programme and clinical trial for hypertension upon the participants. Psychol Med 1977;7:431-8.

6 Macdonald LA, Sackett DL, Haynes RB, Taylor DW. Labelling in hypertension: review of the behavioural and psychological consequences. $f$ Chronic Dis 1984;37: 933-42.

7 Anonymous. More on hypertensive labelling [Editorial]. Lancet 1985;i:1138-9.

8 Steptoe A. Stress mechanisms in hypertension. Postgrad Med f 1986;62:697-9.

9 Jern S. Psychological and hemodynamic factors in borderline hypertension. Acta Med Scand (Suppl) 1982;660:7-54.

10 Karasek R, Baker D, Marxer F, Ahlbom A, Theorell T. Job decision latitude, job demands, and cardiovascular disease: A prospective study of Swedish men. Am f Public Health 1981;71:694-705.

11 Ragland DR, Winkelby MA, Schwalbe J, et al. Prevalence of hypertension in bus drivers. Int $\mathcal{F}$ Epidemiol 1987;16:208-14

12 van Dijk FJH, Ettema JH, Zielhuis RL. Non-auditory effects of noise in industry. VII Evaluation, conclusions and recommendations. Int Arch Occup Environ Health 1987;59: 147-52.

13 Talbott E, Helmkamp J, Matthews K, Kuller L, Cottington E, and Redmond G Occupational noise exposure, noise-induced hearing loss, and the epidemiology of high blood pressure. Am f Epidemiol 1985;121:501-14.

14 Cottington EM, Brock BM, House JS, Hawthorne VM. Psychosocial factors and blood pressure in the Michigan statewide blood pressure survey. Am $\mathcal{F}$ Epidemiol 1985;121: 515-29.

15 Julius M, Harburg E, Cottington EM, Johnson EH. Anger-coping types, blood pressure, and all-cause mortality: a follow-up in Tecumseh, Michigan (1971-1983) Am 7 Epidemiol 1986;124:220-33.

16 James SA. Psychosocial precursors of hypertension: a review of the epidemiologica evidence. Circulation 1987;76(suppl I):60.

17 Strogatz DS, James SA. Social support and hypertension among blacks and whites in a rural, southern community. Am $\mathcal{F}$ Epidemiol 1986;124:949-56.

18 Liebman M, Chopin LF, Carter E, Clark AJ, Disney GW, Hegsted M, et al. Factors related to blood pressure in a biracial adolescent female population. Hypertension related to blood $1986 ; 8: 843-50$.

19 Lindgärde F, Furu M, Ljung B-O. A longitudinal study on the significance of environmental and individual factors associated with the development of essential hypertension. 7 Epidemiol Community Health 1987;41:220-6.

20 Moll PP, Harburg E, Burns TL. Schork MA, Ozgoren F. Heredity, stress and blood pressure, a family set approach: the Detroit project revisited. $\mathcal{F}$ Chronic Dis 1983;36: 317-28.

21 Aro S. Occupational stress, health-related behaviour, and blood pressure: a 5-year follow-up. Prev Med 1984;13:333-48.

\section{Services for sickle cell disease: unified approach needed}

Sickle cell disease is an autosomal recessive disorder affecting one in 30 blacks of Afro-Caribbean origin. ' The prevalence of the carrier state is no less than twice that of cystic fibrosis in the white population..$^{23}$ About the same number of people in the UK suffer from sickle cell disease as from haemophilia A (5000 (C Brown, Policy Studies Institute, London, unpublished observations)) and both the disease and asymptomatic carrier state can be easily detected by a blood test. Some $10-20 \%$ of people die from the disease in the first 10 years of life, ${ }^{45}$ and sufferers have a haemolytic anaemia and recurrent painful vaso-occlusive crises for all their lives. ${ }^{6}$ In later life renal failure and bone necrosis cause chronic disability. Time lost from school leads to poor educational achievement and high unemployment, ${ }^{7}$ and the economic and social cost to an already disadvantaged community is substantial.

The coordination of services for those with sickle cell disease-whether clinical, social, educational, or employment-requires a lead from the Department of Health and Social Security, supported by funding. The department, however, insists that this provision is a matter for district health authorities. ${ }^{8}$ The effect of this policy is apparent from a report, commissioned by the east London branch of the Sickle Cell Society, about services for sickle cell disease in the London Borough of Newham. ${ }^{9}$ This describes an almost total lack of facilities compounded by poor liaison among general practitioners, hospitals, and the community. Inadequate, or incorrect, and condescending advice seems to have been all that was available from health workers. Not surprisingly, the black community perceives this paucity of services as racist, although it would seem familiar to the haemophiliac of 20 to 30 years ago.

Happily, things are improving in Newham, with clinics becoming organised and access to hospital being improved. But it remains difficult to convince health service administrators in general of the scale of the problem and of the need for established funding of educational, screening, and counselling services. "Support," but no money, is usually all that is forthcoming. A satisfactory solution to the medicosocial problems of sickle cell disease could be achieved cheaply using the successful model of haemophilia care, and the scheme could operate under similar sponsorship by the Department of Health. Most of the requirements have already been indentified. ${ }^{2} 10$

In the districts the care of patients with sickle cell disease should be concentrated around a team, comprising the haematologist, paediatrician, and obstetrician, and together they would provide consistent management throughout the patient's life. General practitioners in areas of high incidence of the disease, identified as described in the Newham report, should receive specialised information and training.

Screening pregnant women from ethnic groups with a high incidence of haemoglobinopathies must be followed by testing the partners of carriers. Both antenatal diagnosis and selective abortion of affected pregnancies should then be offered to couples at risk. The Newham survey suggests that people are much more interested in antenatal diagnosis than has been thought.

Sickle cell counsellors have been of immense value in providing support and advice for patients and their families and education and screening for the community. They are also ideally placed to tackle educational and employment problems in both the school and the workplace. Probably one counsellor will be needed for every 50 sufferers and financial support is required urgently to establish these posts nationally.

Optimal management of sickle cell disease from the time of diagnosis at birth should help to reduce the morbidity and mortality in the early years of life, ${ }^{11}$ as well as improving the educational and employment prospects later. Eventually, greater awareness in the black community may lead to a reduction in the number of new cases of sickle cell disease.

In some parts of the UK these results will be achieved because of the efforts of individuals. Nevertheless, to ensure that patients everywhere can obtain specialist care, advice, and support will require a unified approach sponsored by the Department of Health. This will have the additional benefit of showing that professed commitments to ethnic minority health care really have some substance.

IAN M FRANKLIN

Consultant Haematologist,

Queen Elizabeth Hospital,

Birmingham B15 2TH

1 Brozovic M, Anionwu E. Sickle cell disease in Britain. J Clin Pathol 1984;37:1321-6.

2 Stuart J, Schwartz FCM, Little AJ, Raine DN. Screening for abnormal haemoglobins: a pilot study. BrMed $\mathcal{F}$ 1973;iv:284-7.

3 Crofton J, Douglas A. Respiratory diseases. Oxford: Blackwell Scientific Publications, 1981.

4 Mann JR. Sickle haemoglobinopathies in England. Arch Dis Child 1981;138:44-8.

5 Brozovic M, Davies S. Management of sickle cell disease. Postgrad Med J 1987;63:605-9.

6 Serjeant GR. Sickle cell disease. Oxford: Oxford University Press, 1985.

7 Franklin IM, Atkin K. Employment of persons with sickle-cell disease and sickle-cell trait. f Soc Occup Med 1986;36:76-9.

8 Vaughan G. Written answers to questions. House of Commons Official Report (Hansard) 1981 Nov 12;12:col 169.

9 Black J, Laws S. Living with sickle cell disease. London: Sickle Cell Society, East London branch, 1986.

10 Prashar U, Anionwu E, Brozovic M. Sickle cell disease-who cares? London: Runnymede Trust, 1985.

11 Anonymous. Penicillin prophylaxis for babies with sickle cell disease [Editorial]. Lancet 1986;ii: $1432-3$. 